\title{
The Cultural Inheritance of the River Gradac in the Role of Tourism Development in the Area of Valjevo
}

\section{Vesna Matić', Sava Janićević ${ }^{2}$, Slobodan Čerović ${ }^{2}$}

\begin{abstract}
The Gradac gorge represents a most attractive ambient whole and one of the most attractive areas in this part of Serbia. Regardless of the immediate vicinity of Valjevo, which is the economic center of this part of Serbia, the gorge has been preserved to the greatest extent from building and other forms of degradation, the fact which in terms of the total landscape features of this conservation area takes a special place. In the very gorge, there are numerous cultural constructions which are within an easy reach and more or less put to serve tourist purposes. The llovačićs water mill and the monastery of Celije stand out among them.
\end{abstract}

Key words: cultural heritage, Gradac river, tourism, Valjavo
1 Valjevo Secondary School of Economics, Daničićeva 1, 14000 Valjevo, Serbia

2 Department of Geography, Tourism and Hotel Management, Faculty of Sciences, University of Novi Sad, Trg Dositeja Obradovića 3, 21000 Novi Sad, Serbia

\section{Introduction}

In Serbia, there are a few rivers with such interesting hydrographical features of their water currents, the hydro geological peculiarities of the river basin area and direct vital significance for the surrounding population as the river Gradac.

The river Gradac, the water-richest constituent of the river Kolubara, has carved in the south-westerly direction a gorge and canyon-like valley which is $22.7 \mathrm{~km}$ in length. From the Bukovska reka and the Zabava constituents (at an altitude of 364 $\mathrm{m})$, where it actually arises, to the Kolubara estuary (at an altitude of $183 \mathrm{~m}$ ), this river, measured by the riverbed, has $28 \mathrm{~km}$ in length and the overall slope of $187 \mathrm{~m}$. The average slope of only 7 per mill bears witness to a considerably balanced vertical profile. The topographic river basin area of Gradac is $168 \mathrm{~km}^{2}$ and the average flow on a several year basis at Deguric water gauge station amounts to $3028 \mathrm{l} / \mathrm{s}$.

The Gradac gorge, as Radovan Lazarević has labelled it, is carved into the karst terrain of valjevska Podgorina and it deeply cuts the limestone of the karst of Lelić, that is to say the karst of Valjevo. The geological structure of the terrain, which is highly dominated by limestone rocks, has significantly influenced the formation of morphographic and hydrological characteristics of the valley.

The main morphological peculiarity of the Gradac gorge is meandering winding of the lower part of the valley, which is closer to the riverbed. The compacted meandric curves with limestone meandric marshes on opposite sides, whose tops are 50 to $60 \mathrm{~m}$ above the river, narrow the bottom of the valley to the space of mere 5 to $20 \mathrm{~m}$. The main morphological peculiarity of the Gradac gorge is meandering winding of the lower part of the valley, which is closer to the riverbed. Only at some sectors of the valley, i.e. downstream from the Zabava and the Bukovska reka constituents, at Gradac railway stop and somewhat upstream from there is the valley bottom widened up to a hundred meters or so. The depth of the gorge in relation to the level of the area it is cut into amounts to average $150-200 \mathrm{~m}$ and it is highest in the upstream part between the villages of Bačevci and Gornje Leskovice, where it amounts to over $300 \mathrm{~m}$. The gorge sides are steep, very often vertically hewn, represented by limestone cliffs.

The springs of the Gradac, which arise from two flowing zones, are especially interesting. The first upstream source is called Zelenci and it is represented by 7 water springs on the left riverside, placed along the distance of a hundred metres or so. The first one is the strongest. It spurts from the rocky material directly above the riverbed. Other springs arise at a low alluvial plane over which they flow into the Gradac water current. The second zone of outflow is about $250 \mathrm{~m}$ downstream on the right side of the concave part of the river meander. Most of the year the seepage of this spring, which is called Kolovrat, is masked by the Gradac water current, to be more precise by the water of Zelenci spring.

In 1987, the construction of the $\mathrm{Ty}$ rol water pump in the Gradac riverbed at about $3.5 \mathrm{~km}$ away from the Kolubara estuary, at the altitude of $198 \mathrm{~m}$, as well as that of the water pumping station and a pipeline leading to the water purification plant, made these rivers integrate into the water supplying system of Valjevo, with 250 to $300 \mathrm{l} / \mathrm{s}$. Having done so, the dearth of water in Valjevo, especially during the summertime, had been disposed of for a while. With regard to these facts, the protection of the water quality of the Gradac and the whole gorge area are of life importance for this town (Institute for nature conservation of Serbia, 1998).

Diverse flora and fauna in the water and around it beautify the Gradac gorge. The river itself is a typical mountain watercourse, one of the cleanest in Serbia, and the water quality ranges from I A to I B class. The river Gradac has special significance for the water supplying of the town from the locality called Ploče, where the water pump is. The Gradac is one of the 


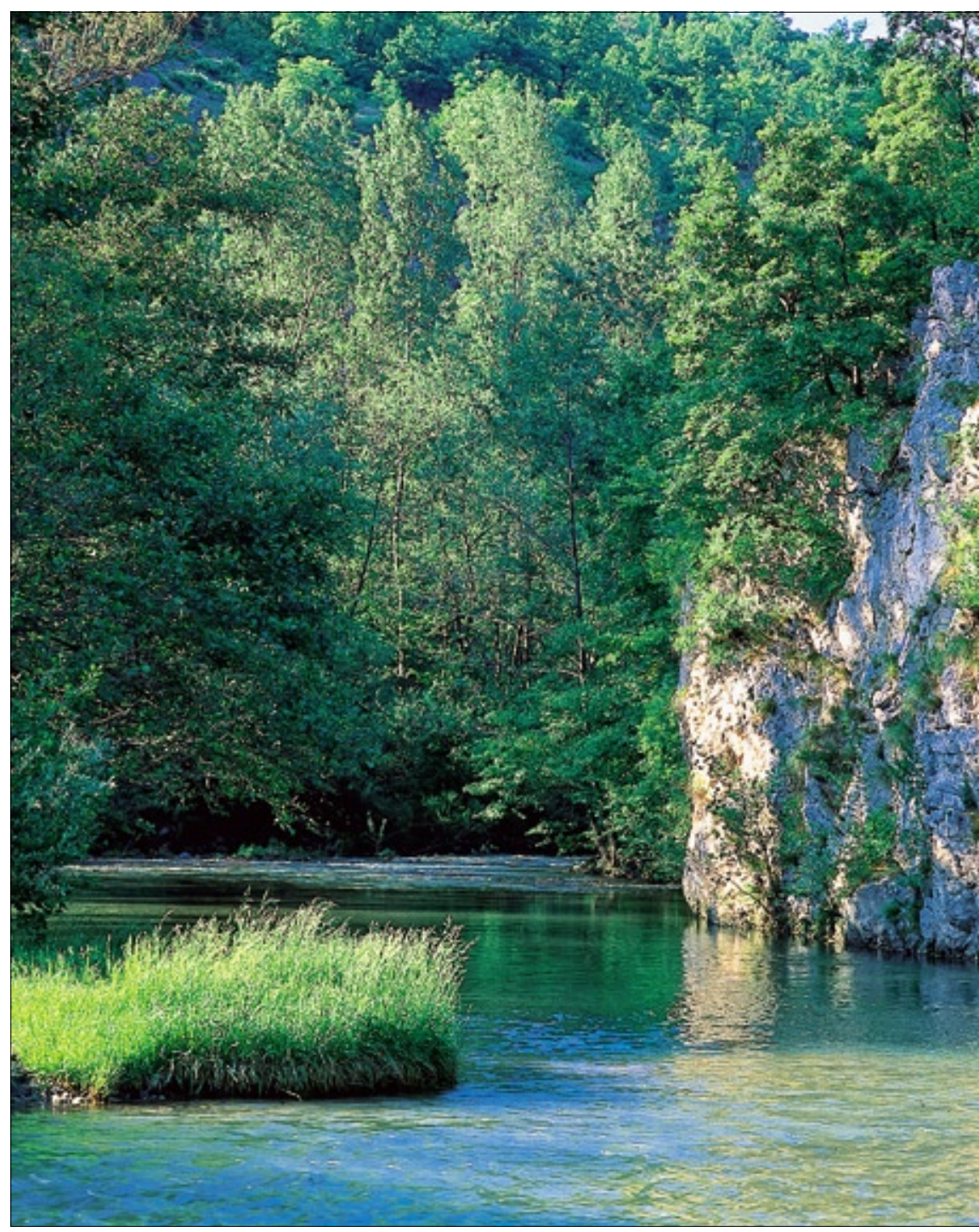

Figure 1 Gradac river (photo M. Jeremić)

favourite picnic areas for Valjevo inhabitants. A large number of caves are a speleological challenge and sacral constructions, especially the monasteries of Lelić and Ćelije give this area an exceptional spiritual and historical value.

Not many inhabitants live in the very gorge. The villages are situated around the edge of the gorge and they are linked to the town by the roads that extend along the same edge. Year on year, the number of inhabitants has been decreasing.

The area of approximately 1300 ha, with its diversity and its characteristics utterly justifies the reasons for being put under protection. For more than two decades (since 1984), this area has been receiving a certain level of protection. Originally it was an area under the protection initiated and carried out by the local government and later as an area where the work of attention and management was performed by a non-governmental organization, which is a curiosity even within the European frame. The area has been under the state protection since 2001. The protection proposal was realised in 1998 (Institute for nature conservation of Serbia, Bel-

Figure 2 Zelenci spring (photo M. Jeremić) grade) and it was suggested then that the ities of the second class' and Gradac Environmental Society from Valjevo was nominated as its custodian.

The municipality council of Valjevo made a verdict on protection on $25^{\text {th }}$ FebGradac gorge be 'an area of exquisite qual- ruary, 2001, by adopting recommendations made by the Republic Environment Protection Bureau. "The River Gradac gorge", the conservation area has henceforth been the only environmental property within the municipality of Valjevo where the protection is carried out completely. This property has been legally marked, the programmes and plans for the protection and development are being realized and the legally recognized internal order is put into effect within its frontiers. The whole area is under the supervision of the custodians which are the municipal and republic inspectorates and the Institute for nature conservation of Serbia. The oldest international institution for environment protection, the IUCN, has also been its custodian since 2004. Simultaneously, various training programmes in the fields of environment protection and research, autochthonous animal species regeneration (gray partridge) and artistic performances have been carried out.

Illegal construction represents an exceptional problem and so far it has not endangered the survival of this property. However, it could become the major problem because the construction of illegal buildings is always followed by that of new ones, the latter citing the existence and survival of the former ones (Valjevo municipality, 2004).

The Gradac gorge represents a most attractive ambient whole and one of the most attractive areas in this part of Serbia. Regardless of the immediate vicinity of Valjevo, the economic center of this part of Serbia, the gorge has been preserved to a great extent from construction and other forms of degradation The Gradac gorge represents a most attractive ambient whole and one of the most attractive areas in this part of Serbia. Regardless of the immediate vicinity of Valjevo, which is the economic center of this part of Serbia, the gorge has been pre

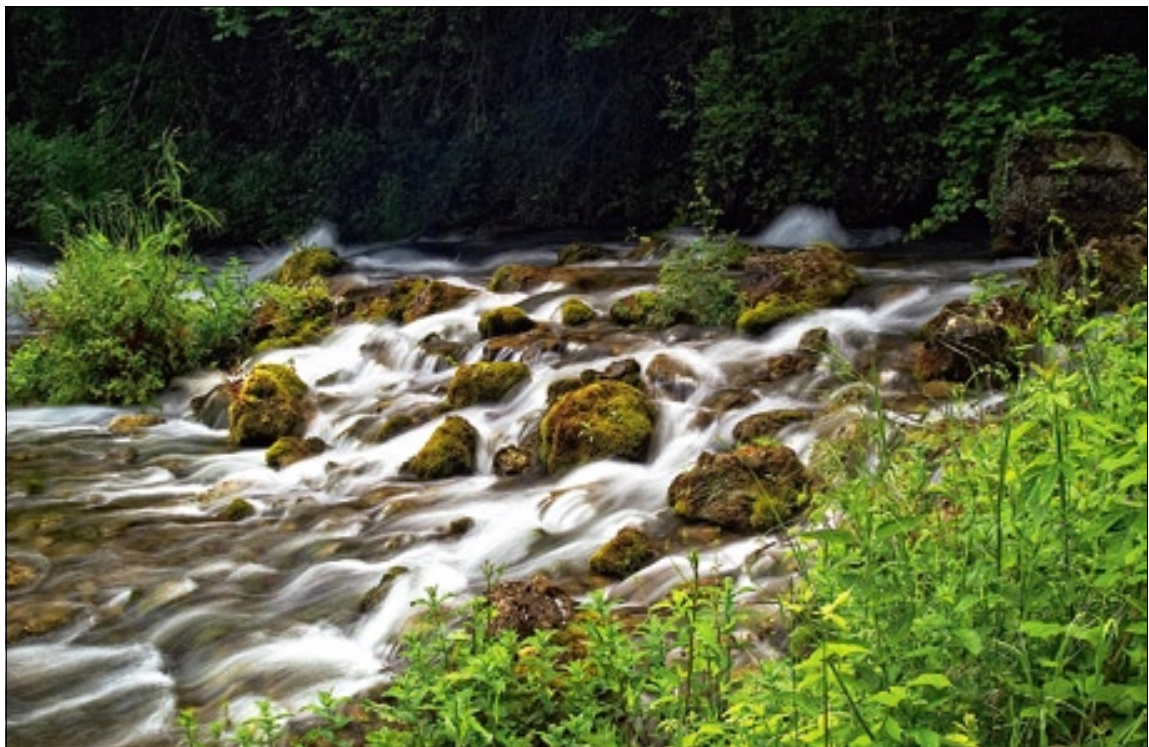


served to the greatest extent from building and other forms of degradation, the fact which among the total landscape features of this environmental property takes a special place. A special quality of the gorge is a large number of spatially small localities which are highly esteemed in terms of ambient values as well as many natural hill peaks, it is hills from which you can observe not only some parts of the gorge but its farther surroundings, too.

\section{Cultural and Historical Values of the River Gradac Gorge}

Due to the geographical characteristics of the gorge itself (it is well-sheltered and has good defensive possibilities), especially because it is located in the contact zone between the mountains of Valjevo and the fertile valley of the Kolubara, the immediate environs of the gorge has been inhabited since long ago.

The oldest remains date back to the Palaeolithic and Neolithic period and they refer to the settlements of hunters and original farmers. They have been unearthed in the High cave in the gorge, in the nearby Petnicka cave and at other localities in close proximity.

The gorge area was inhabited during the Roman ages, too. Here there was (about $10 \mathrm{~km}$ south-west from Valjevo) a castrum, which in the Roman military doctrine means a larger fortification for the accommodation of border troops. The castrum protected the Roman road which ran through the valley of the Gradac and it was a part of the second line of defence from the invasions of barbaric tribes from the north.

During the Slavic settlement, the continuity of populating smaller and larger fortifications was disrupted. In the social organization of the new arrival tribes, there was no room for these fortifications so they remained deserted for long.

In the Middle Ages, at the time when Serbian state was being established, the constructions, which would in a more or a less changed condition remain to this day, were built. (Valjevo municipality, 1998).

\section{Archaeological sites}

The fortification of Jerina town in the village of Brangović stands for the largest fortification in this area.

The archaeological evidence has proved that life within the fortification was going on in the period from the $4^{\text {th }}$ till the $7^{\text {th }}$ century. Two layers of conflagration and devastation have been ascertained, one dating from the first half of the $5^{\text {th }}$ century, the other from the end of the $6^{\text {th }}$ century, which shows that the fortification was first captured by the Huns and later by the Slavic and Avarians. Minor evidence has been registered, which indicates that life was also going on in the period from the $7^{\text {th }}$ to the $10^{\text {th }}$ century, during the Serbian settlement. Architectural remains and the situation obtained by geodetic survey and excavations point to a large number of buildings in the abovementioned area. These buildings point to the existence of a significant civic settlement which grew up next to the ancient road that went through the canyon of the Gradac. The settlement had probably been fenced off with tower ramparts which enclosed the space of about four hectares. A church, which has been completely explored, has been discovered in the lower part of the town. This church was a one nave construction, the dimensions being $13 \mathrm{~m}$ by $9 \mathrm{~m}$. The walls, which were built from compressed stone and mortar, have been preserved up to the height of $2 \mathrm{~m}$. A stony seat for an archbishop and priests called sinthronos has been found in the erside within the area of the village of Lelić near Valjevo. A legend has it that it is a memorial of King Dragutin (1276-1282). Another legend has it that the monastery was built up at the turn of $14^{\text {th }}$ century during despot Stefan Lazarevićs reign. In a Turkish census dating from 1560 , the monastery of Bogomolje near the village of Lelić in the Valjevo nachia is mentioned. It is thought that this monastery is identical to that of Ćelije. Ruvim, a monk and a cell scribe, is mentioned in 1720 and in 1733 on the agreement of Serbian leaders in Belgrade, Danilo Vukašinović, a cell prior also takes part. In 1774, in the monastery of Ćelije, Rafailo, the future pastor of the village of Babaluka, well-known as Hadži Ruvim, was ordained. In $1783 / 84$, five monks were living here.

Monks had a hand in inciting an uprising against Turks. For this reason, notorious pasha Bushatlia at the beginning of

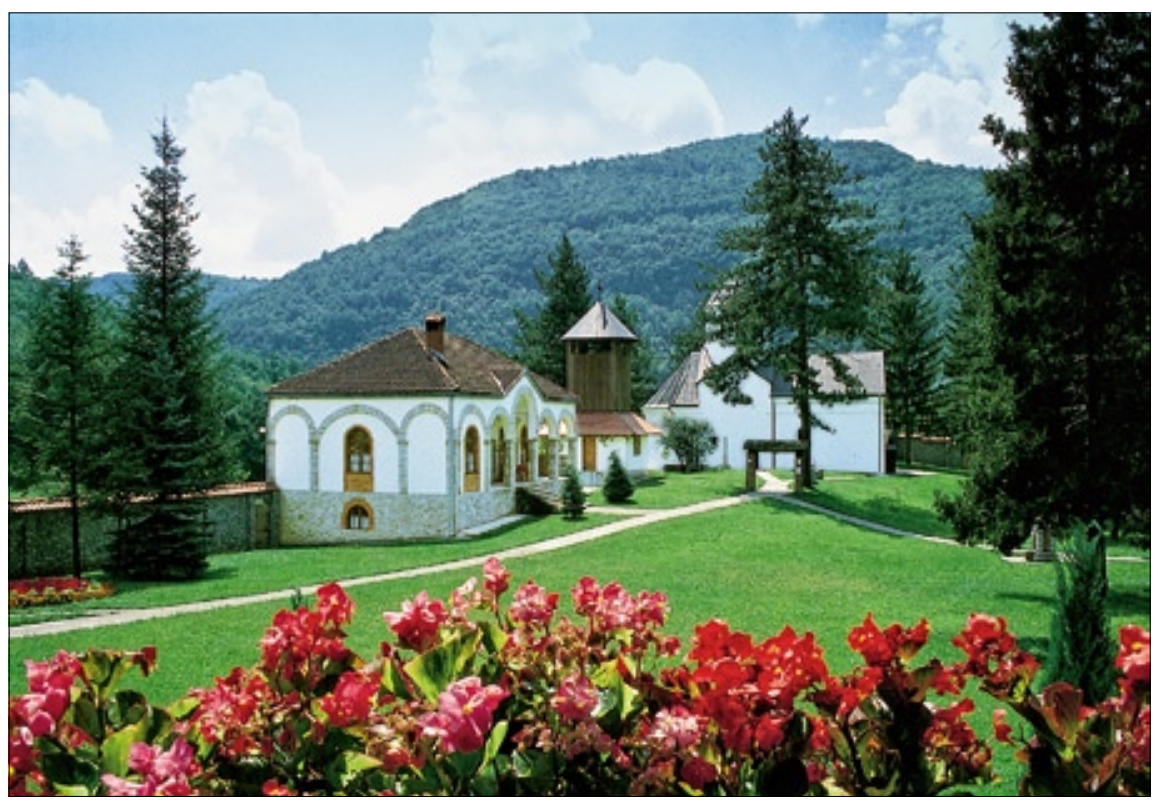

Figure 3 Ćelije Monastery (photo M. Jeremić)

altar apses, which points to the occasional or permanent services of an archbishop in this church.

On the right side of the river, close to the Kolubara estuary, there is a medieval archaeological site. The existence of the remains of a church, of a necropolis and a settlement, which grew up and lasted from $14^{\text {th }}$ till $17^{\text {th }}$ century, has been ascertained. This archaeological site was discovered during the construction of a football stadium and much was damaged then. Nowadays, one can see beside the stadium enclosure the remains of the church walls but further research in view of the construction built up over this site has not been carried out (the data obtained from the Historical Monuments Protection Bureau).

\section{The Monastery of Ćelije}

From the cultural and historical aspect, the monastery of Ćelije is certainly the most significant one. It is positioned on the left riv-
1791 set alight the monastery of Ćelije along with other thirteen churches from the area of Valjevo. The monastery was reconstructed in 1793. During prior Simon Ćelijski, monks together with the treasured possessions moved away to Srem and they found a temporary residence in the monastery of Grgeteg. Karadjordje's hospital was set in the monastery of Ćelije. Turks set it ablaze again in 1810 but in the following year it was already renovated. A new dome and a parvis were erected. After the first Serbian uprising, the cell monks fled to Srem again but they returned soon. During prior Dionysius, in 1816, Jeremija Mihailović from Bajevac painted the iconostasis. From 1837 till 1928, the monastery of Ćelije was a parish church. During $19^{\text {th }}$ century, one of the first primary schools in liberated Serbia worked there. In 1963, a monastery konack (a place to stay overnight) dedicated to Saint Jovan Zlatousti was built up and the great dinning room dates back from 1978. 


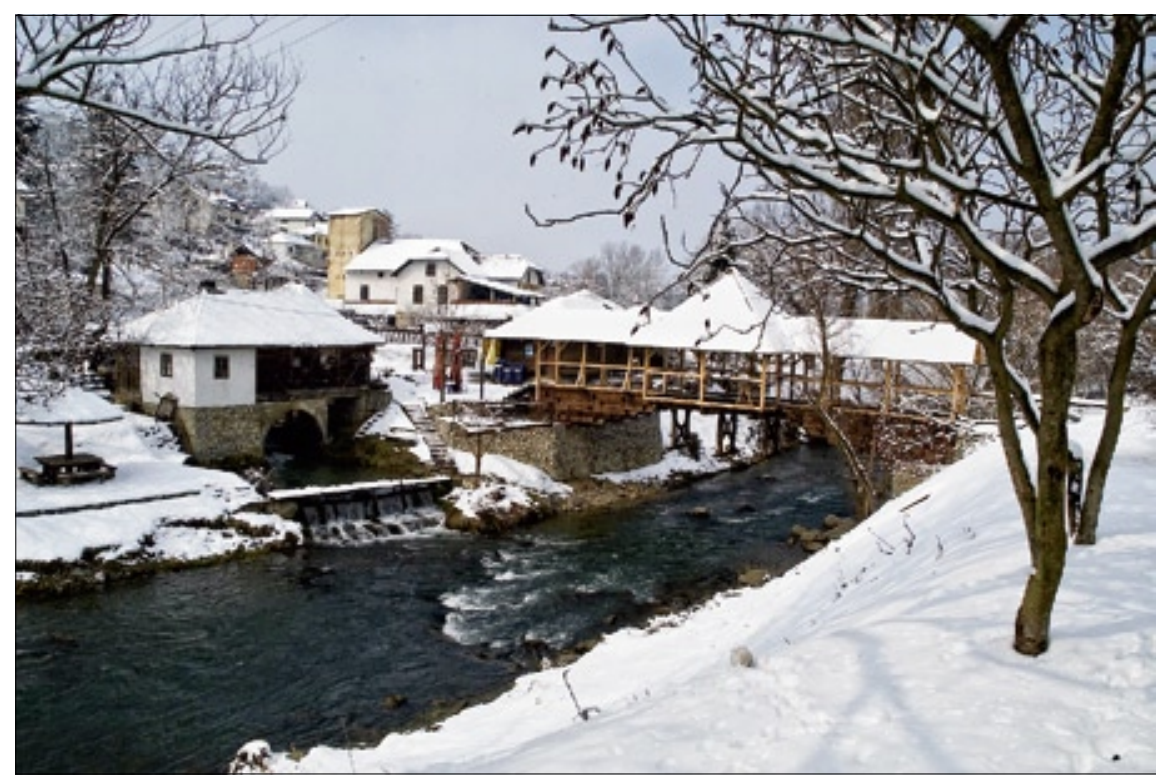

Figure 4 llovačić's water mill (photo M. Jeremić)

In 1983, another floor was added on to the konack of 1963 (Mileusnić, 2002).

The basis of the monastery is in the shape of a single nave structure with unusual outward appearance of the dome. The belfry is on the north side of the church and it was erected in 1926

The iconostasis, painted by Petar Nikolajević Moler, an artist and a Serbian uprising duke, was destroyed in 1810 . The new iconostasis was painted by Petar's nephew, Jeremija Mihailović. On the left side of the church towards the altar, there is "an enclosure of the duke under mount Medvednik", the grave of Ilija Birčanin who was executed by the Turkish dahias at a bridge over the Kolubara in Valjevo in 1804. On the south side of the altar, there is the grave of Ave Justin who died in 1979. There is a school of iconography in which nuns from this monastery create. It also has a developed publishing work. The monastery of Ćelije is a convent.

\section{The Ilovačić's water mill}

At the end of downtown Tešnjar, at an open ground further from a bridge over the Kolubara, there was an old water mill, well-known as the Ilovačićs water mill. It was built up at the ground where Jevrem Obrenović's palace was. Nobody knows for sure whether Jevrem himself put it up or he had found it there. Joakim Vujić, in his memoirs pointed out that above the palace fence there was a four mill stoned water mill on the Kolubara, which brought its master huge profit. For a time the water mill was yielded to Jakov Nenadović, who kept it until 1836 and it has been leased ever since. After that it has been well-known as the Ilovačićs water mill.

It had been in use until $6^{\text {th }}$ May, 1955 when it stopped working and became a derelict building, which no one tended to any longer.
As it was in bad condition and on the verge of collapse and to leave it at the same place was illusory for it was impossible to make it operational again, it was dislocated into the conservation zone of the Gradac in 1989. In the lower part of the water current it was put into functioning (the data obtained from the Historical Monuments Protection Bureau).

Today, flour is ground in the Ilovačićs water mill and wooden handicrafts are sold

The water mill is positioned at the opening of the promenade up the Gradac gorge; there is a café in the immediate vicinity and the Tadića mlin restaurant is nearby. A new wooden bridge has been constructed next to it. As it works almost all year around, one can visit it and at the same time see how flour is ground on the water millstone.

Going further from the water mill to the dam, a rolling mill comes into view. It has not been put into operation but together with a few other examples of popular ar- chitecture in close proximity, it makes this area a specific setting and reminds us of Milovan Glišić's day and his short stories.

Going further up the Gradac gorge, one can see other few water mills among which the Novakovićs and Sava's water mills.

\section{The hydroelectric power plant in Deguric}

As early as in 1808 , Prota Mateja made great effort for a paper manufacturing plant and he yielded his water mill, which was at the same place where after 90 years his grandson Mateja would build up the first public hydroelectric central station in Serbia. At first, electricity was used only for the street illumination and later on with affluent citizens. Finally, others started using electricity. Soon after the power station had been built, they realized that it was not enough to meet the needs of electricity supplying of Valjevo. In view of this, Mate Nenadović bought in Degurić, on the Gradac, the Pavlovićs estate intending to build here a hydroelectric power plant, which would be connected with Valjevo. By the contract of 1901 he sold his business to Phinneus. He went into partnership with the Fegeli brothers and and Julius Schmidt from Belgrade.

The hydroelectric power plant in Degurić was erected by Phinneus, the Fegelis and Schmidt between 1902 and 1903. It consisted of the 135 horsepower Francis turbine which was exposed to the water height of fall of 6.5 metres. With the assistance of the 8o-watt alternating dynamo, it generated the electricity of 3200 in voltage. Along with the construction of the dam, a long-distance power line to Valjevo with two or three transformers was built.

At the beginning of 1903, the partnership of Phinneus, the Fegelis and Schmidt fell apart. As the proprietors of the town illumination concession, they were divided.

After the end of the First World War Phinneus and the Fegelis conferred their

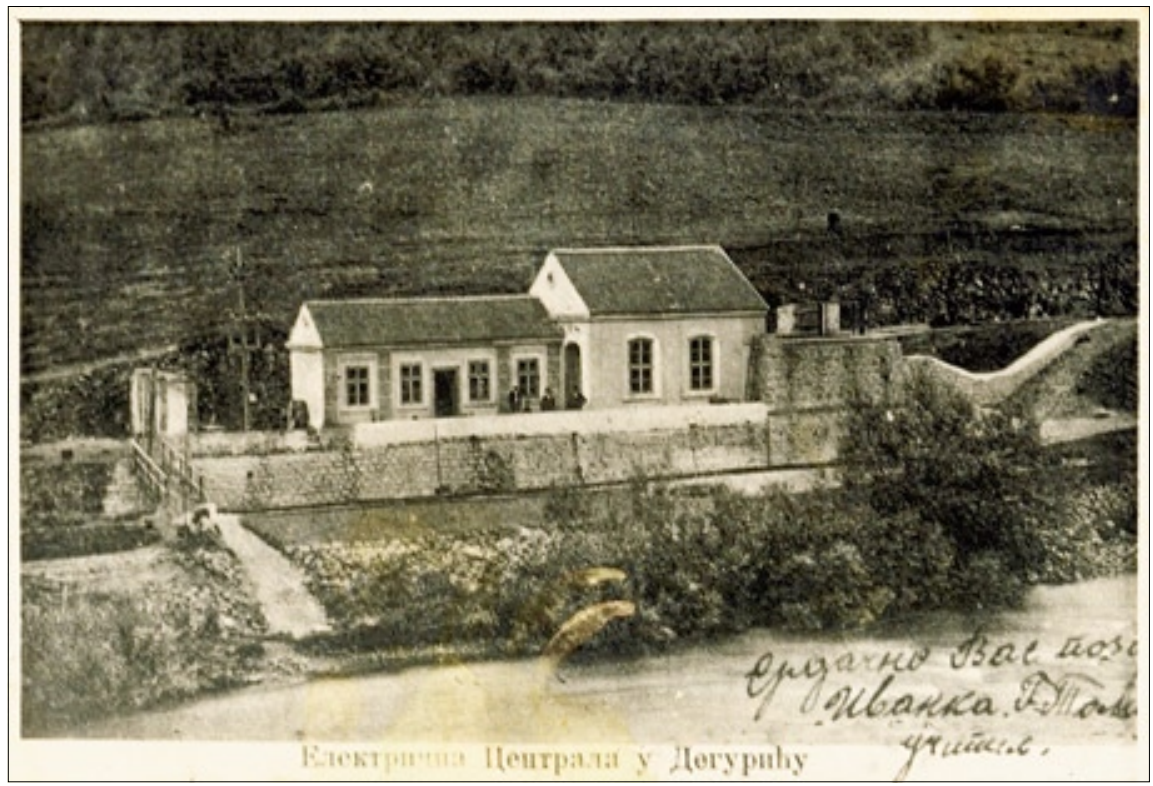

Figure 5 Hydroelectric power plant in Degurić (Historical archive Valjevo) 
rights to Schmidt, who in 1923 sold the company to Stevan Unković, a manufacturer from Valjevo. He remained its proprietor until 1945. At that time, Svetlost Electrical Industry Company was established and this hydroelectric power plant was integrated into it (the data obtained from the Historical Monuments Protection Bureau).

As the old hydroelectric power plant is within the enclosed space in which there is also a fish pond, tourists are denied access into this area. Although a lot of people move around this part of the gorge, where there is the Deguric cave and other attractive parts of the gorge, many of them don't know that only a few paces away from the enclosure along which they walk there is one of the first Serbian hydroelectric power plants.

\section{The Material Basis and Spatial Organization}

The Gradac gorge is a favourite picnic area of Valjevo inhabitants. There is a road built alongside the river, which one can take and move along the valley of this river, from its estuary to its source. For a few kilometers, it is a wide asphalt road that makes it possible for you not only to cross certain distances by car but to use the favourite Valjevo inhabitants' means of transport - a bicycle as well. The road is on the right riverside whereas on the left one at some points there are paths. During the summer months, especially in the last couple of years, the traffic has presented us with an enormous problem. The road is too narrow for pedestrians (with children and pets), cyclists, motorbikes, cars and lorries to move along at the same time. This creates great problems especially at weekends and it takes huge skillfulness for impatient drivers to come to terms. Intolerable noise, which also disturbs the peace of this conservation area, is made. Several parts of the foreshore, where possible, have been turned into minor riverbank beaches on which younger generations spend summer months, paying no attention to the relatively low water temperature. Swarms of people move along this area during the summer and at weekends. All of them run away from the town noise and heat, looking for refreshment and shade by the river. For these reasons, not a few people go as far as Sunčani ili Kraljev whirlpools.

Along the very path and the riverside, there are few illegally built catering buildings, mostly cafés, which do not intrude into its harmony. At the very opening, there is the Tadića mlin restaurant in which domestic cuisine dishes are served and the home bred trout is in demand. At a few places in the gorge, there are fish ponds so one can buy fish there.

Spatial organization is at a pretty high level. Although there are no waste paper baskets, the consciousness and the need for the preservation of this area with the inhabitants of Valjevo is fully expressed so that one can rarely find refuse and oth er material evidence of human habitation. At a few places in the gorge, there are (not enough) notice boards showing the basic characteristics of this property. The marking of natural properties such as the Degurić cave also takes place. One can have a longer stay in the area of the gorge in lodging houses.

\section{Cultural Inheritance in the Role oof Tourism}

The Gradac still serves primarily as a picnic area and when tourism values of this gorge are under discussion, one most often refers to the natural values whereas cultural ones are put in the background.

A tour around the Gradac and the cultural sights in the gorge does not exist as a guided tour on offer. The only ones who take their guests on a tour of this natural property and its cultural sights are members of the Host Society. They organize for their guests a tour of Valjevo, Tešnjar and the Gradac by carriage. The carriages are rented as taxis and if weather permitting they are parked at the taxi rank next to the museum.

The monastery of Ćelije is indisputably the most famous of all cultural sights that are in the Gradac gorge. However, a small number of tourists are directed to go along the gorge because the path has not been cleared at one section and one must walk by the railroad, which is pretty risky. Beside the indisputable artistic and historical values that the monastery of Celije possesses, there are two prominent men from the area of Valjevo in direct connection with it - they are Ilija Birčanin and Ava Justin Popović. Both of them rest in the churchyard and the canonization of Ave Justin is all the more reason to popularize this monastery. In addition to this, a few kilometers away from this monastery, there is the monastery of Lelic in which bishop Nikolaj rests. Good connections with the monastery of Lelić and the fact that two saints rest at such a short distance along with the easy reach from all directions is something on which the future promotion of this area should be based upon. The hydroelectrical power plant is one of the rare industrial constructions in our regions, which was preserved and pronounced a cultural monument. Considering the fact that the old equipment is no longer in use, it should be repaired, conserved and turned into a museum exhibition which could be located in an appropriate building within the hydroelectrical power plant. However, prior to this, one must first introduce the public into the existence of the power plant, put it into tourism role. This would be feasible since the privately owned catering business next to it has a trout fish pond and it would be nice to arrange a decent catering construction in which tourists could make a break on their way to the nearby Degurić cave.

Making the Ilovačićs water mill operational at the very opening of the promenade and creating a unique appearance was the right move made by the Historical Monuments Protection Bureau. In the future, the rolling mill, which is in close proximity, should also be made operational.

\section{Conclusion}

The Gradac gorge is a beautiful area which the inhabitants of Valjevo for selfish reasons rarely show to tourists. Tourists in the area of Valjevo visit Brankovina, Divčibare, monasteries and Tešnjar but they rarely visit the Gradac.

The Gradac is distinguished from other watercourses primarily by its position, the connection with the town and at the same time by the feasibility of combining natural and cultural tourism values at a relatively small space, which gives a unique experience to everyone who sets out along this river.

A high priority should be placed on solving the traffic problem and later on the path to the monastery of Ćelije should be marked. The archaeological sites should also be marked and the hydroelectrical power plant in Degurić should be put into tourist function. The riverbank should be occasionally regulated and benches should be placed on several places. Camping and barbecuing sites should be marked, too. One must endeavour to preserve the natural values of the gorge and make the outing and rural tourism remain a dominant form of tourist movement.

The river Gradac, with all its values is something that Valjevo should take pride in. It should also, with the solution of the existing communal problems and the prevention of further illegal construction, turn this area into a true pearl in its tourist offer.

\section{References}

Institute for nature conservation of Serbia. 1998. A Proposal for putting the Gradac gorge as an area of exquisite qualities under the protection. Institute for nature conservation of Serbia, Belgrade

Valjevo municipality. 2004. A Local eco-action plan of the Municipality of Valjevo. The first working paper. Valjevo, 53-54

Mileusnić S. 2002. The Monasteries of Serbia - A Comprehensive Illustrated Encyclopedia, Volume 2, published by Pravoslavna reč, Belgrade, 517-1037.

The data obtained from the Historical Monuments Protection Bureau. 